\title{
医療環境中に污染された抗がん阂を可視光応答型光触媒にて分解する試み
}

\author{
佐 藤 淳 也, ${ }^{*, a, b}$ 菊 地 聡 美, ${ }^{a}$ 工藤 賢 三 $a, b$
}

\section{Degrading Anticancer Drugs in the Medical Environment Using a Visible Light-driven Photocatalyst}

\author{
Junya Sato, ${ }^{*, a, b}$ Satomi Kikuchi, ${ }^{a}$ and Kenzo Kudo ${ }^{a, b}$ \\ ${ }^{a}$ Department of Clinical Pharmaceutics, School of Pharmacy, Iwate Medical University; \\ 2-1-1 Nishitokuda, Yahaba-cho, Shiwa-gun, Iwate 028-3694, Japan: and \\ ${ }^{b}$ Department of Pharmacy, Iwate Medical University Hospital; \\ 19-1 Uchimaru, Morioka, Iwate 020-8505, Japan.
}

(Received March 1, 2014; Accepted May 14, 2014)

\begin{abstract}
Occupational exposure to anticancer drugs is recognized as a risk for healthcare workers. Reducing anticancer drugs in the environment is important to prevent the exposure of individuals to anticancer drugs. However, there are currently no effective degrading agents for all anticancer drugs used in clinical settings. We previously reported the resolution of an anticancer drug with the use of a photocatalyst $\left(\mathrm{TiO}_{2}\right)$, which acts by absorbing ultraviolet light to degrade organic compounds. In this study, we evaluated anticancer drug degradation using a visible light-driven photocatalyst $(\mathrm{Cu} /$ $\mathrm{WO}_{3}$ ). Anticancer drugs [cyclophosphamide (CPA), paclitaxel (PTX), methotrexate (MTX), irinotecan (CPT-11), cytarabine (Ara-C), and 5-fluorouracil (5-FU)], were experimentally deposited on a stainless steel plate. The visible light-driven photocatalytic agent $\left(0.075 \% \mathrm{Cu} / \mathrm{WO}_{3}\right.$ solution $)$ was sprayed onto the plate, and the plate was then left under a fluorescent lamp for $12 \mathrm{~h}$. The anticancer drugs remaining on the plate were assayed by high-performance liquid chromatography (HPLC). CPA, PTX, MTX, CPT-11, Ara-C, and 5-FU were found to be degraded by up to $37.7 \%$, $>99.0 \%, 57.1 \%, 54.6 \%, 69.5 \%$, and $36.3 \%$, respectively. The visible light-driven photocatalyst was therefore confirmed to degrade anticancer drugs under a fluorescent lamp. The ability of the visible light-driven photocatalyst to degrade multiple chemotherapeutic agents without the need for altering the light source could make it a useful tool for reducing anticancer drug pollution in clinical settings.
\end{abstract}

Key words - occupational exposure; anticancer drug; visible light-driven photocatalyst; copper modified tungsten oxide; cyclophosphamide

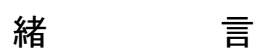

近年，医療従事者の職業的な抗がん剂被曝による 健康被害が危惧されている。その背景には，医療従 事者の尿中から抗がん剤が検出されたとする人体的 被曝や調製室, 生物学的安全キャビネット（biological safety cabinet; BSC) 内における環境被曝が ある。ささらに医療従事者における抗がん剤の被曝 は，流産などの生殖毒性や発がんのリスク増になる ことが報告されている. ${ }^{1-3)}$ これら職業的抗がん剂 被曝を防ぐには，グローブ及びマスク，ガウンなど

The authors declare no conflict of interest.

$a$ 岩手医科大学薬学部臨床薬剤学講座, $b$ 岩手医科大学 附属病院薬剂部

*e-mail: junya02377@nifty.com
の個人防御具を着用し，BSC 内で抗がん剂の調製 を行うことが重要である。ささらにシクロホスファミ ドなど気化する抗がん風については，閉鎖式調製器 具を使用することが現状で最善の防御策である。し かし，これら被曝対策の適正化を行っていても，環 境的な抗がん剂污染が存在するのが事実である。そ こで，抗がん剂に污染された環境では，化学的な分 解液を用いて残留抗がん剂を分解し，清拭すること が必要である，わが国のガイドラインでは，生物学 的安全キャビネット内の清拭に $0.3 \mathrm{M}$ 水酸化ナトリ ウム水を基本に, 污染した薬剤種に応じて $2 \%$ 次亜 塩素酸ナトリウム水あるいは $1 \%$ チオ硫酸ナトリウ

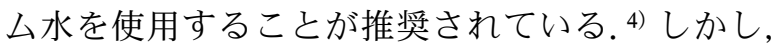
これらすべての分解液は, 使用薬剂毎に使い分ける 点，一部に人体に刺激性がある点，使用後に水拭き 
除去しなくてはならない点で使用が煩雑である。さ らに，一般にシクロホスファミドなど一部の抗がん 剂は，これら分解液を使用しても被分解性は乏し く, 密封し焼却することが最終的な処理である。つ まり，現時点において抗がん剂污染に対して安全か つ十分に効果的な分解剤は存在しない.

これまでわれわれは, 光エネルギーから活性酸素 を産生し，有機物を分解する特性を有する光触媒に

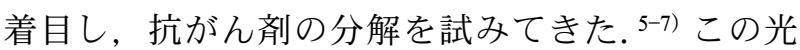
触媒とは，二酸化チタン（ $\mathrm{TiO}_{2} ）$ を代表とし，人 体に無害な紫外線（波長域 $400 \mathrm{~nm}$ 以下）の光エネ ルギーから活性酸素を産生する半導体である，光触 媒から発生する活性酸素による抗菌性や空気清浄 · 脱臭能などが，生活関連から医療産業にまで広く応 用されている，そこで， $\mathrm{TiO}_{2}$ を主成分とする抗が 儿剂分解剂を作製し，複数の抗がん剂に対する分解

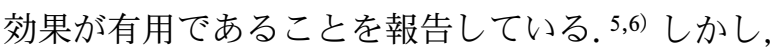
$\mathrm{TiO}_{2}$ を主成分とする光触媒は，光源として紫外線 を必要としているため BSC 内部など適用範囲が限 られていた。 そこで今回，光源として紫外線に代わ り蛍光ランプなどあらゆる環境に照射される可視光 に応答する光触媒を用い，その抗がん剂分解能を評 価した.

\section{方法}

\section{1. 可視光応答型光触媒剤の調製 可視光応答} 型光触媒は，銅・酸化タングステン $\left(\mathrm{Cu} / \mathrm{WO}_{3}\right)$ の $10 \%$ スラリー液 [ルミレッシュ CWS-2 ; 昭和電工 秼］を含む水溶液 $\left[\mathrm{Cu} / \mathrm{WO}_{3}\right.$ として $\left.0.075 \%(\mathrm{w} / \mathrm{v})\right]$ とした。これに既報に準じて濡れ性と垂直面への付 着性を持たせるためにアルコール系濡れ性改良剤 $5.8 \%(\mathrm{w} / \mathrm{v})$ ，ポリアクリル酸系粘度調整剂 $0.6 \%$ （w/v）を加えて試験製剤とした。

2. 光触媒性能の試験方法 分解対象としての 抗がん剂としては，シクロホスファミド［cyclophosphamide; CPA，注射用エンドキサン $100 \mathrm{mg}$, 塩野義製薬侏］のほか，構造や作用機序の異なる計 6 種の抗がん剂［5-フルオロウラシル（5-fluorouracil; 5-FU (特級), 和光純薬(侏), シタラビン (cytarabine; Ara-C，キロサイド注 $20 \mathrm{mg}$, 日本新薬(侏), メトトレキサート (methotrexate; MTX，メソトレ キセート点滴静注液 $200 \mathrm{mg}$, ファイザー(侏)，パク リタキセル（paclitaxel; PTX，タキソール注射液
$30 \mathrm{mg}$ ，ブリストル・マイヤーズ(侏)，イリノテカ ン（irinotecan; CPT-11，トポテシン点滴静注 40 $\mathrm{mg}$, 第一三共( $\left(⿰^{\prime}\right)$ ）について検討した. 光触媒による 抗がん剂分解能の評価方法は，安全キャビネットに 使用されるものと同材質のステンレス板 (SUS304 ; $10 \mathrm{~cm} \times 10 \mathrm{~cm} ）$ に，各濃度に調製した抗がん剂を $10 \mu \mathrm{L}$ ずつ 25 個の水滴となるようピペットを用い て均等（5 列 $\times 5$ 行； $16 \mathrm{~mm}$ 間隔）に滴下した。滴 下した抗がん剂溶液を室温にて 30 分間乾燥後, 加 圧式スプレーに充填した可視光応答型光触媒溶剂を $50 \mathrm{~g} / \mathrm{m}^{2}$ の用量でステンレス板に噴霧した（光触媒 群)。対照としては, 可視光応答型光触媒溶剂の代 わりに，同様に蒸留水を噴霧したものを使用した (対照群)。ただし，CPT-11 評価時の対照群として は，可視光の光照射のみにて $50 \%$ 以上の分解が認 められたため, 可視光応答型光触媒溶剂を噴霧した 後遮光した. 可視光応答型光触媒溶剤あるいは水を 噴霧したこれらのステンレス板は，安全キャビネッ 卜内で蛍光ランプ下に 12 時間放置した。可視光線 の照射条件としては，安全キャビネット［SterilChemGARD III ${ }^{\circledR}$; SG-603ATX，日科ミクロン侏］ 内部 $(\mathrm{W} 1978 \times \mathrm{D} 776)$ 天井に, $15 \mathrm{~W}$ 型蛍光ラン プ（三菱照明； FL15EX-N）を 4 本設置し，その照 度は（平均 $2000 \mathrm{~lx}$ ）であった。

3. 残留抗がん風の測定方法 残留抗がん剂の 分析は, 脱脂綿を用いてステンレス板を $5 \mathrm{~mL}$ の蒸 留水にて拭き取り, その回収液を高速液体クロマト グラフィー（HPLC）の分析サンプルとした。本拭 き取り方法による回収率は，95\%以上であった。

HPLC による抗がん剤の定量条件は, Table 1 に示 した.

4. 統計処理 測定は, 光触媒群及び対照群と も各抗がん剤滴下量について，6 枚のステンレス板 を用いて行い，拭き取り回収した抗がん剂量を平均 化した。両群の測定值は, unpaired $t$-testにて統計 処理を行い, 危険率 $5 \%$ 未満を有意差ありとした. 光触媒による抗がん剂の分解率（\%）は， $\{1-$ (光 触媒群平均值/対照群平均值) $\} \times 100$ にて算出した.

結

果

Table 2 に可視光応答型光触媒による分解条件を 示した。 CPA 及び PTX, MTXにおいて遮光条件 あるいは光触媒の代わりに蒸留水を噴霧した場合, 
Table 1. HPLC Analysis Conditions

\begin{tabular}{|c|c|c|c|c|c|c|}
\hline Drug & CPA & $5-\mathrm{FU}$ & Ara-C & MTX & PTX & CPT-11 \\
\hline $\begin{array}{c}\text { Column } \\
\text { (particle size, } \\
\text { diameter } \times \text { length })\end{array}$ & & $\begin{array}{c}\text { LiChrosorb }^{\circledR} \text { RP-8 } \\
\quad(5 \mu \mathrm{m}, \\
4.6 \mathrm{~mm} \times 250 \mathrm{~mm})\end{array}$ & & & $\begin{array}{c}\text { Shodex }^{\circledR} \mathrm{C} 18 \mathrm{P} 4 \mathrm{E} \\
(5 \mu \mathrm{m}, \\
4.6 \mathrm{~mm} \times 250 \mathrm{~mm})\end{array}$ & \\
\hline $\begin{array}{c}\text { Column } \\
\text { temperature }\left({ }^{\circ} \mathrm{C}\right)\end{array}$ & 40 & 40 & 40 & 40 & 40 & 40 \\
\hline Mobile phase & $\begin{array}{l}\text { water/acetonitrile } \\
\quad=75 / 25\end{array}$ & $\begin{array}{l}10 \mathrm{~mm} \text { acetic } \\
\text { acid/methanol } \\
\quad=90 / 10\end{array}$ & $\begin{array}{l}50 \mathrm{~mm} \text { phosphate } \\
\text { buffer }(\mathrm{pH} 6.8) / \\
\text { methanol }=98 / 2\end{array}$ & $\begin{array}{l}2 \mathrm{mM} \text { acetic } \\
\text { acid/methanol } \\
\quad=80 / 20\end{array}$ & $\begin{array}{l}\text { acetonitrile/ } \\
\text { water/methanol } \\
=50 / 30 / 20\end{array}$ & $\begin{array}{c}50 \mathrm{mM} \mathrm{KH}_{2} \mathrm{PO}_{4}, \\
7.5 \mathrm{mM} \mathrm{Bu} \mathrm{BBr}_{4} / \\
\text { acetonitrile } \\
=83 / 17\end{array}$ \\
\hline $\begin{array}{l}\text { Flow rate } \\
(\mathrm{mL} / \mathrm{min})\end{array}$ & 1.0 & 1.0 & 1.0 & 1.0 & 1.0 & 1.0 \\
\hline $\begin{array}{l}\text { Injection volume } \\
(\mu \mathrm{L})\end{array}$ & 20 & 20 & 20 & 20 & 20 & 20 \\
\hline $\begin{array}{c}\text { Detector } \\
\text { wavelength (nm) }\end{array}$ & 195 & 260 & 254 & 307 & 236 & 254 \\
\hline $\begin{array}{l}\text { Determination } \\
\text { limit }(\mu \mathrm{g} / \mathrm{mL})\end{array}$ & 5 & 0.1 & 0.25 & 0.25 & 0.25 & 1 \\
\hline
\end{tabular}

The conditions under which HPLC analysis of anticancer drugs was conducted to evaluate their degradation with the visible light-driven photocatalyst are shown.

Table 2. Degradation with the Photocatalyst

\begin{tabular}{|c|c|c|c|c|}
\hline Drug & $\begin{array}{l}\text { Loading } \\
\text { dose }(\mu \mathrm{g})\end{array}$ & Spray & Light & $\begin{array}{l}\text { Recovery dose } \\
(\text { mean } \pm \text { S.D. }\end{array}$ \\
\hline \multirow{6}{*}{$\begin{array}{l}\text { CPA } \\
(n=2)\end{array}$} & \multirow{6}{*}{100} & Photocatalyst & $(+)$ & $54.6 \pm 1.9$ \\
\hline & & Photocatalyst & $(-)$ & $82.9 \pm 0.0$ \\
\hline & & DW & $(+)$ & $103.5 \pm 4.5$ \\
\hline & & DW & $(-)$ & $104.1 \pm 2.8$ \\
\hline & & $(-)$ & $(+)$ & $115.1 \pm 12.5$ \\
\hline & & $(-)$ & $(-)$ & $116.5 \pm 34.5$ \\
\hline \multirow{6}{*}{$\begin{array}{l}\text { MTX } \\
(n=6)\end{array}$} & \multirow{3}{*}{500} & Photocatalyst & $(+)$ & $172.7 \pm 126.0$ \\
\hline & & Photocatalyst & $(-)$ & $484.4 \pm 60.6$ \\
\hline & & DW & $(+)$ & $402.9 \pm 24.9$ \\
\hline & \multirow{3}{*}{100} & Photocatalyst & $(+)$ & $30.9 \pm 26.4$ \\
\hline & & Photocatalyst & $(-)$ & $73.2 \pm 30.2$ \\
\hline & & DW & $(+)$ & $59.7 \pm 6.2$ \\
\hline \multirow{6}{*}{$\begin{array}{c}\text { PTX } \\
(n=6)\end{array}$} & \multirow{3}{*}{100} & Photocatalyst & $(+)$ & $18.3 \pm 12.8$ \\
\hline & & Photocatalyst & $(-)$ & $107.3 \pm 1.7$ \\
\hline & & DW & $(+)$ & $102.6 \pm 5.9$ \\
\hline & \multirow{3}{*}{50} & Photocatalyst & $(+)$ & UD \\
\hline & & Photocatalyst & $(-)$ & $49.5 \pm 5.5$ \\
\hline & & DW & $(+)$ & $48.2 \pm 1.7$ \\
\hline
\end{tabular}

Values are mean \pm S.D. Loading doses are shown as micrograms per 100 $\mathrm{cm}^{2}$. Distilled water (DW) was sprayed on plates as a control for comparison with the activity of the photocatalyst. UD, under the determination limit; CPA, cyclophosphamide; PTX, paclitaxel; MTX, methotrexate.

これら抗がん闵の大きな分解を認めなかった。 Table 3 に各種濃度の抗がん剂負荷量に対する対照群 及び光触媒溶液群の回収量を示した。 また，対照群 と光触媒群の回収量から算出した光触媒による分解 率を Fig. 1 に示した. CPA については，いずれの
Table 3. Recovery of Various Anticancer Drugs by the Photocatalyst

\begin{tabular}{|c|c|c|c|c|}
\hline Drug & $\begin{array}{l}\text { Loading } \\
\text { dose }(\mu \mathrm{g})\end{array}$ & $\begin{array}{l}\text { Control group } \\
\quad(n=6)\end{array}$ & $\begin{array}{l}\text { Photocatalyst } \\
\text { group }(n=6)\end{array}$ & $p$-value \\
\hline \multirow{3}{*}{ CPA } & 4000 & $4224.2 \pm 122.4$ & $2660.9 \pm 870.8$ & 0.001 \\
\hline & 1000 & $1066.5 \pm 25.2$ & $664.2 \pm 293.1$ & 0.007 \\
\hline & 500 & $520.5 \pm 21.7$ & $325.7 \pm 141.9$ & 0.008 \\
\hline \multirow{4}{*}{ PTX } & 300 & $326.1 \pm 4.6$ & $289.5 \pm 60.8$ & 0.172 \\
\hline & 200 & $209.2 \pm 20.8$ & $87.7 \pm 97.6$ & 0.014 \\
\hline & 100 & $102.6 \pm 5.9$ & $18.3 \pm 12.8$ & 0.000 \\
\hline & 50 & $48.2 \pm 1.7$ & UD & 0.000 \\
\hline \multirow{4}{*}{ MTX } & 2500 & $2476.8 \pm 123.9$ & $1367.0 \pm 722.0$ & 0.004 \\
\hline & 1000 & $924.3 \pm 44.1$ & $507.4 \pm 193.6$ & 0.000 \\
\hline & 500 & $402.9 \pm 24.9$ & $172.7 \pm 126.0$ & 0.001 \\
\hline & 100 & $59.7 \pm 6.2$ & $30.9 \pm 26.4$ & 0.027 \\
\hline \multirow{4}{*}{ CPT-11 } & 2000 & $1907.6 \pm 172.7$ & $865.9 \pm 347.9$ & 0.000 \\
\hline & 1000 & $932.9 \pm 127.1$ & $430.9 \pm 46.8$ & 0.000 \\
\hline & 400 & $370.3 \pm 31.6$ & $202.1 \pm 42.4$ & 0.000 \\
\hline & 100 & $94.5 \pm 6.6$ & $53.4 \pm 9.9$ & 0.000 \\
\hline \multirow{4}{*}{ Ara-C } & 500 & $536.5 \pm 31.4$ & $442.7 \pm 44.0$ & 0.002 \\
\hline & 100 & $109.3 \pm 5.5$ & $62.9 \pm 7.2$ & 0.000 \\
\hline & 50 & $59.6 \pm 7.5$ & $28.0 \pm 5.1$ & 0.000 \\
\hline & 10 & $10.6 \pm 0.4$ & $3.2 \pm 0.8$ & 0.000 \\
\hline \multirow{3}{*}{$5-\mathrm{FU}$} & 500 & $480.9 \pm 38.7$ & $451.5 \pm 16.4$ & 0.116 \\
\hline & 100 & $107.1 \pm 7.8$ & $68.2 \pm 34.3$ & 0.022 \\
\hline & 50 & $52.3 \pm 5.5$ & $41.6 \pm 4.3$ & 0.004 \\
\hline
\end{tabular}

Values are mean \pm S.D. $(n=6)$. Loading doses are shown as micrograms per $100 \mathrm{~cm}^{2}$. UD, under the determination limit; CPA, cyclophosphamide; PTX, paclitaxel; MTX, methotrexate; CPT-11, irinotecan; AraC, cytarabine; 5-FU, 5-fluorouracil. 


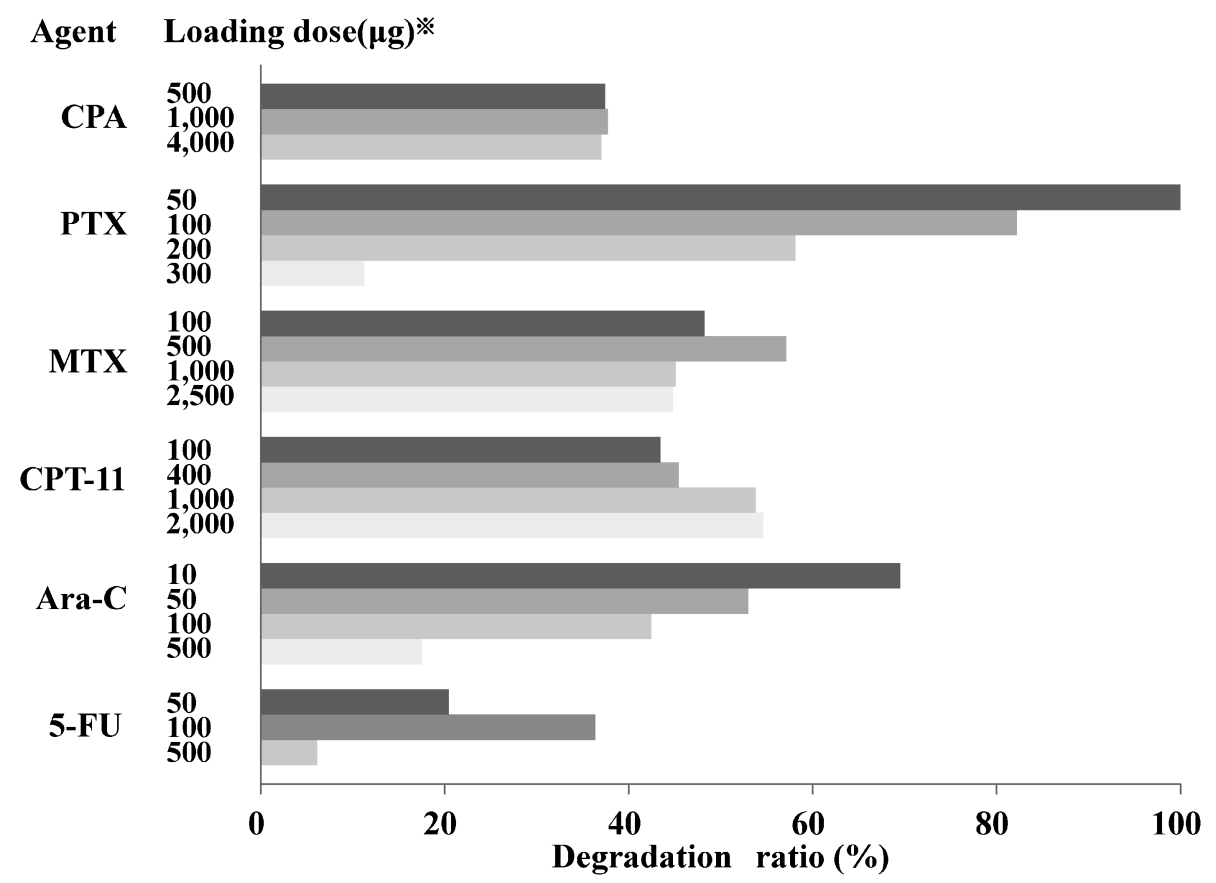

Fig. 1. Degradation Rates of Various Anticancer Drugs by the Photocatalyst

The degradation rate $(\%)$ was calculated as (1-average quantity of recovery with the photocatalyst group/control group) $\times 100$. $*$ Loading doses are shown as micrograms per $100 \mathrm{~cm}^{2}$. CPA, cyclophosphamide; PTX, paclitaxel; MTX, methotrexate; CPT-11, irinotecan; Ara-C, cytarabine; 5-FU, 5-fluorouracil.

負荷量（500，1000 及び $4000 \mu \mathrm{g} / 100 \mathrm{~cm}^{2} ）$ におい ても光触媒群の回収量は統計的有意に低 $<$, 分解率 は 37.0-37.7\%であった。PTXについては，50， 100 及び $200 \mu \mathrm{g} / 100 \mathrm{~cm}^{2}$ の負荷量において光触媒群 の回収量は統計的有意に低く, 分解率は 58.1$>99.0 \%$ あっった。 ただし，より高用量である 300 $\mu \mathrm{g} / 100 \mathrm{~cm}^{2}$ においては, 統計的有意な分解を認め なかった。MTXについては，いずれの負荷量 (100，500，1000 及び $\left.2500 \mu \mathrm{g} / 100 \mathrm{~cm}^{2}\right)$ において も光触媒群の回収量は統計的有意に低く, 分解率は 45.1-57.1\%であった. CPT-11については，いずれ の負荷量（100，400，1000 及び $2000 \mu \mathrm{g} / 100 \mathrm{~cm}^{2}$ ） においても光触媒群の回収量は統計的有意に低 $<$, 分解率は 43.5-54.6\%であった。 Ara-Cにおいて は，いずれの負荷量（10，50，100 及び $500 \mu \mathrm{g} / 100$ $\left.\mathrm{cm}^{2}\right)$ においても光触媒群の回収量は, 統計的有意 に低く，分解率は 17.5-69.5\%であった．5-FUにつ いては，50 及び $100 \mu \mathrm{g} / 100 \mathrm{~cm}^{2}$ の負荷量において 光触媒群の回収量は有意に低く，分解率は 20.4$36.3 \%$ あ゙った．ただし，より高用量である $500 \mu \mathrm{g}$ $/ 100 \mathrm{~cm}^{2}$ においては, 統計的に有意な分解を認め なかった。

\section{考察}

光触媒には，これまで $\mathrm{TiO}_{2}$ が広く使用されてお り，これに波長域 $400 \mathrm{~nm}$ 以下の紫外線光を照射す ると, 酸化物表面から電子が放出されると同時に, プラス電荷を持った正孔が生じる半導体である，環 境中の酸素は，マイナス電子と反応しスーパーオキ サイドアニオン $\left(\cdot \mathrm{O}_{2}^{-}\right)$を生じ，正孔では水から 電子を奪い取り，ヒドロキシラジカル $(\cdot \mathrm{OH})$ が 発生する. 特に, 強い酸化力を持つヒドロキシラジ カル $(\cdot \mathrm{OH})$ は, 有機分子中の $\mathrm{C}-\mathrm{C}$ 結合, $\mathrm{C}-\mathrm{H}$ 結合， $\mathrm{C}-\mathrm{N}$ 結合， $\mathrm{C}-\mathrm{O}$ 結合， $\mathrm{O}-\mathrm{H}$ 結合， $\mathrm{N}-\mathrm{O}$ 結 合の結合解離エネルギーより大きな酸化エネルギー を持つ.したがって，あらゆる有機化合物の原子間 結合を容易に切断し，分子を分解する. $\left.{ }^{8}\right)$ 光触媒の このような特性は, 防衛研究の分野におけるシクロ ホスファミドと類似構造を持つマスタード系毒ガス の分解, ${ }^{9)}$ 環境衛生の分野における下水中のステロ イドホルモンの分解, ${ }^{10)}$ 大腸菌や黄色ブドウ球菌な どの細菌群, インフルエンザなどのウイルスや酵 母, 真菌の殺菌 ${ }^{11)}$ などが報告されている. しかし, 医療分野，特に環境的に残留する抗がん剂の分解に 光触媒を応用する事例は，これまでほとんど報告さ 
れていない。

われわれは，これまで残留する抗がん剂の污染が 甚大かつ特有の紫外線光源の得られる BSC 内の抗 がん剂の分解に, 光触媒 $\left(\mathrm{TiO}_{2}\right)$ を用いた分解剂 を作製し，その効果を検証した。 その結果， CPA が最大 $50 \%$ 分解されたのを始め PTX や CPT-11, MTX，5-FU など複数の抗がん剂が最大 $>99 \%$ 分解 されることを検証した。特にCPA は，無精子症， 卵巣機能不全，無月経，催奇形性などの生殖毒性を 有し，World Health Organization（WHO）の設け た国際がん研究機関 (International Agency for Research on Cancer; IARC) の発がん性に関する分 類においては，ヒトに対する発がん性が確実と分類 されている環境被曝のメルクマールとなる抗がん剂

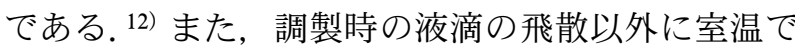
気化するため, あらゆる医療環境で検出されてい る.しかし現在，抗がん剂の分解液として推奨され ている $0.3 \mathrm{M}$ 水酸化ナトリウム水溶液中でも, CPA はわずか $28.5 \%$ しか分解されず， 1 回の拭き取り清 拭では，残留抗がん剂を完全に除去することが困難 であると考えられる. ${ }^{13)}$ これまでの成績により，光 触媒を用いた抗がん剂分解剂は，被分解性に乏しい CPA のみならず，あらゆる抗がん剤を分解できる 有用なツールとなる可能性を示した。しかし， $\mathrm{TiO}_{2}$ を主成分とする光触媒は，光源として紫外線 を必要としており，その適用範囲が限られていた。 今回，われわれの用いた可視光応答型光触媒は，独 新エネルギー・産業技術総合開発機構（NEDO） の開発した銅系化合物修飾酸化タングステンであ り，室内光として汎用される波長 $400 \mathrm{~nm}$ 以上の蛍 光ランプ下においても活性を示し，高い効率でアセ トアルデヒドや大腸菌を分解することが報告されて いる. ${ }^{14,15)}$ したがって, 可視光応答型光触媒は, 効 率の高さと光源を選ばない点でこれまでの $\mathrm{TiO}_{2}$ を 主成分とした光触媒と比べ，適用範囲が飛躍的に拡 大されることが期待されており，公共施設トイレの 脱臭や医療機関の感染防止に応用が試みられてい る. ${ }^{16,17)}$

今回，可視光応答型光触媒を主成分とした分解剂 を作製し，抗がん剂の飛散状況に模して実験的に作 製した抗がん剤滴下面にこれを噴霧した結果， CPA を始め複数の抗がん剂が統計的有意に分解さ れた．光源として用いた白色蛍光ランプは，可視光
応答型光触媒の吸収スペクトル ${ }^{14)} に$ 合致する 400 $\mathrm{nm}$ 以上の可視光を発生（三菱照明総合カタログ 2013-2014, p. 651） していることや Table 2 に示し た通り，これら抗がん剤の分解は，光触媒の代わり に水の噴霧又は光触媒を噴霧しても蛍光ランプを遮 光すると認められないことから，光触媒の特性に由 来するものと考えられた。しかし，分解率には，負 荷した抗がん剤の種類や量により差を認めた。ま た，同一の抗がん剂においても負荷した抗がん剂量 に対して分解能の差異を認めた。 $\mathrm{TiO}_{2}$ を用いた既 報の検討では，分解対象の抗がん剂負荷量が減るに 従い，分解率が向上する傾向を認めたが，今回の可 視光反応型光触媒では，PTX 及びAra-C を除い て，高濃度の負荷において分解能が頭打ちになる傾 向を認めた。これらの理由としては，分解対象物で ある抗がん剤の(1)構造の違い，(2)負荷した抗がん剂 (医薬品）の添加物の影響, (3)抗がん剂の液性（pH や粘性，水への溶解性）などが影響したものと思わ れる，例えば，PTX は元々水に難溶なので粘性の ある界面活性化剈（ポリオキシエチレンヒマシ油） が混合されており，そのためステンレス板に滴下後 も光触媒液を噴霧してもほとんど乾燥し難いもので あった. したがって, 後に光触媒液を噴霧しても乾 燥した他の抗がん剂の状況と異なり混和され易かつ た可能性がある。また，Ara-C は，PTX 以外の他 薬剂同様に滴下後乾燥したが，比較した抗がん剂の 中で唯一水に溶解し易い特性があるため光触媒液を 噴霧すれば再度溶解し，容易に光触媒と混和して分 解反応が促進されたことも推測される.しかし，可 視光反応型光触媒と $\mathrm{TiO}_{2}$ を主成分とした光触媒の 分解率を同じ抗がん剂負荷量にて比較すると, 負荷 量 $4000 \mu \mathrm{g}$ の CPA 分解率は，可視光反応型光触媒 と $\mathrm{TiO}_{2}$ においてそれぞれ $37 \%$ 及び $22 \%$ であり， $1000 \mu \mathrm{g}$ においてそれぞれ $38 \%$ 及び $30 \%$ であるよ うに濃度によってはほぼ同等の抗がん剤分解能を認 めた。これまでわれわれは，実際の抗がん剂調製環 境において污染実態を評価した結果，BSC 外の CPA 及び 5-FU の污染は, 最大 $0.013 \mathrm{ng} / \mathrm{cm}^{2}$ 及び $36 \mathrm{ng} / 100 \mathrm{~cm}^{2}$ であった. ${ }^{18)}$ さらに，他報告におい てもCPA 及び $5-\mathrm{FU}$ 污染の範囲は, 最大 $0.053 \mathrm{ng} /$ $\mathrm{cm}^{2}$ 及び $24 \mathrm{ng} / \mathrm{cm}^{2}$ であると報告されている. ${ }^{19)} こ$ れに対して実験的な負荷量は，定量装置（HPLC） の定量範囲から CPA について 5-40 $\mu \mathrm{g} / \mathrm{cm}^{2}$ 及び 
5-FU については，0.5-5 $\mu \mathrm{g} / \mathrm{cm}^{2}$ と高いものにせざ る得なかつた。 また, 可視光応答型光触媒の濃度 は，現実的な臨床応用された際のコストを考慮して 設定した。 反応時間も既報における光触媒剤 $\left(\mathrm{TiO}_{2}\right)$ が夜間使用しない $\mathrm{BSC}$ 内に残留する抗が ん剤の分解を想定し 12 時間としたが，用途の変わ る可視光応答型光触媒においては，これらが適切な のか熟慮する必要があると思われた。したがって, 可視光応答型光触媒の濃度や反応時間に関する疑問 を解決するためにも，これを用いて実際の医療現場 の污染が低減するか検討する必要があると思われた。

以上より，今回検討した可視光応答型光触媒を用 いた分解剤は, 蛍光ランプ下においても抗がん剂の 分解能を認めた．光源を選ばず，あらゆる抗がん剂 を分解する特性は，污染の甚大な BSC 内部のみな らず，調製室や病室への応用も可能であると思わ れ，医療現場の抗がん剂污染を低減する有用なツー ルとなると思われた。

謝辞本研究は, 日本学術振興会の科学研究費 助成事業（課題番号：25460219）の助成を受けたも のである.また，可視光応答型光触媒を用いた本研 究の遂行にあたり技術的アドバイスを頂きました昭 和電工侏樋口靖展氏並びに五大化成侏瀧本 功氏に 御礼申し上げます。

\section{REFERENCES}

1) Sessink P. J., Kroese E. D., van Kranen H. J., Bos R. P., Int. Arch. Occup. Environ Health, 67, 317-323 (1995).

2) Sugiura S., Itoh A., Tanimura M., Nakanishi H., Hama T., Miyagawa M., Mori K, J. Jpn. Soc. Hosp. Pharm., 44, 18-20 (2008).

3) Selevan S. G., Lindbohm M. L., Hornung R. W., Hemminki K., N. Engl. J. Med., 313, 1173-1178 (1985).

4) Japanese Society of Hospital Pharmacists, "Chushazai koganyaku mukinchosei guide- line," YAKUJI NIPPO LIMITED, Tokyo, 2008, pp. 23-35.

5) Sato J., Kudo K., Takimoto I., Sanbayashi M., Kijihana I., Takahashi K., Jpn. J. Pharm. Health Care Sci., 37, 57-61 (2011) .

6) Sato J., Kudo K., Takimoto I., Sanbayashi M., Umezawa T., Kijihana I., Takahashi K., Jpn. J. Pharm. Health Care Sci., 37, 585-589 (2011).

7) Sato J., Kudo K., Hirano T., Kuwashima T., Yamada S., Kijihana I., Sato K, Takahashi K., Yakugaku Zasshi, 132, 1189-1195 (2012) .

8) Taoda H., Synthesiology, 1, 287-295 (2008).

9) Hirakawa T., Mera N., Sano T., Negishi N., Takeuchi H., Yakugaku Zasshi, 129, 71-92 (2009) .

10) Ohko Y., Iuchi K., Niwa C., Tatsuma T., Nakashima T., Iguchi T., Kubota Y., Fujishima A., Environ. Sci. Technol., 36, 4175-4181 (2002).

11) Watabe T., Sunada K., Hashimoto K., Inorganic Materials, 6, 532-540 (1999).

12) International Agency for Research on Cancer (IARC), IARC Monogr. Eval. Carcinog. Risks Hum. Suppl., 7, 182 (1987).

13) Mochizuki C., Fujikawa I., Tei G., Yoshida J., J. Jpn. Soc. Hosp. Pharm., 44, 601-604 (2008).

14) Irie H., Miura S., Kamiya K., Hashimoto K., Chem. Phys. Lett., 457, 202-205 (2008).

15) Kuroda Y., Hosogi Y., JCS-Japan, 45, 10061009 (2010).

16) Fujii H., Photocatalysis, 40, 40-47 (2013).

17) Miki S., Photocatalysis, 40, 36-39 (2013).

18) Sato J., Mori M., Sasaki T., Nihei S., Kumagai M., Nakayama S., Takahashi K., Kudo K., Yakugaku Zasshi, 134, 751-756 (2014) .

19) Nakano H., Yoshida J., Komori K., Mochizuki C., Nakata Y., Tei G., Masu Y., Koda S., Nishida S., Jpn. J. Pharm. Health Care Sci., 39, 1-9 (2013). 